\title{
GAMBARAN PENGELOLAAN PERSEDIAAN OBAT DI GUDANG FARMASI RSUD SYEKH YUSUF GOWA
}

\author{
Fais Satrianegara ${ }^{1}$, Syarfaini $^{2}$, Syamsiah Adha ${ }^{3}$, Nurul Iwanah Husain ${ }^{4}$ \\ ${ }^{1,4}$ Bagian Administrasi Rumah Sakit Universitas Islam Negeri Alauddin Makassar \\ ${ }^{2,3}$ Bagian Gizi Universitas Islam Negeri Alauddin Makassar
}

\begin{abstract}
ABSTRAK
Mutu pelayanan yang diberikan rumah sakit sangat berpengaruh terhadap citra rumah sakit dan kepuasan pasien yang berkunjung kerumah sakit tersebut. Salah satu faktor yang berperan terhadap mutu pelayanan rumah sakit adalah pengelolaan obat yang dilakukan di rumah sakit. Pengelolaan obat perlu untuk dilakukan untuk mencegah terjadinya kekurangan obat (stock out), kelebihan obat (over stock), dan pembelian obat secara cito. RSUD Syekh Yusuf Gowa pernah terjadi kekosongan obat yang disebabkan oleh peningkatan jumlah pasien. Tujuan dalam penelitian ini untuk mengetahui gambaran manajemen pengelolaan persediaan obat di Gudang Farmasi RSUD Syekh Yusuf Gowa. Jenis penelitian ini adalah penelitian kualitatif dengan pendekatan studi kasus. Pengambilan sampel pada penelitian ini menggunakan Teknik Non Random (Non Probability) Sampling dengan metode purposive sampling. Informan dalam penelitian ini terdiri dari Kepala Instalasi Farmasi, Penanggung Jawab Sediaan Obat dan BMHP, Pengelola Obat dan Pengelola BMHP. Hasil penelitian menunjukkan bahwa pengelolaan persediaan obat di gudang farmasi RSUD Syekh Yusuf Gowa sudah cukup efektif, tetapi ada beberapa faktor yang dapat mempengaruhi kekosongan obat. Hal ini terlihat dari beberapa komponen Input (Sarana terutama gudang penyimpanan yang kurang representatif), Proses (ketidakkonsistenan terhadap penggunaan sediaan, perencanaan yang kurang teliti, suhu ruangan yang berubah-ubah mempengaruhi sediaan yang ada, keterlambatan pelaporan sediaan yang kosong dan kelalaian petugas yang mengakibatkan sediaan menjadi rusak dan expired) dan Output (sudah sesuai dengan kebutuhan). Diharapkan kepada Kepala Instalasi Farmasi RSUD Syekh Yusuf Gowa untuk mempertimbangkan penambahan luas gudang farmasi yang dianggap belum cukup memadai, pengadaan pendingin ruangan yang sesuai dengan standar dan diharapkan kepada petugas gudang untuk lebih teliti dalam proses perencanaan sediaan untuk meminimalisir sediaan yang terlupa.
\end{abstract}

Kata kunci :Pengelolaan persediaan obat, Gudang Farmasi, Rumah Sakit.

\section{PENDAHULUAN}

Mutu pelayanan yang diberikan rumah sakit sangat berpengaruh terhadap citra rumah sakit dan kepuasan pasien yang berkunjung kerumah sakit tersebut. Salah satu faktor yang berperan terhadap mutu pelayanan rumah sakit adalah pengelolaan obat yang dilakukan di rumah sakit. Pengelolaan obat perlu untuk dilakukan untuk mencegah terjadinya kekurangan obat (stock out), kelebihan obat (over stock), dan pembelian obat secara cito. Apabila pasien tidak memperoleh pengobatan sebagaimana mestinya dikarenakan 
ketersediaan obat yang selalu tidak ada, maka membuat pasien merasa tidak puas dan berdampak buruk dengan citra rumah sakit tersebut (Haryanti dkk, 2015). Menurut WHO di Negara berkembang, biaya obat sebesar 24-66\% dari total biaya kesehatan. Belanja obat yang demikian besar tentunya harus dikelola dengan efektif dan efisien.

Berdasarkan data Ditjen Kefarmasian dan Alat Kesehatan 2017 mengenai instalasi farmasi kabupaten/kota yang telah melakukan manajemen pengelolaan obat dan vaksin sesuai target, sebagian besar provinsi telah memenuhi target $60 \%$, yaitu 26 provinsi, tetapi masih terdapat 8 provinsi yang belum mencapai target Renstra 2016 diantaranya Maluku, NTT, Banten, Sulawesi Selatan, Sumatera Utara, Papua Barat, Sulawesi Barat dan DKI Jakarta. Provinsi yang paling rendahialah DKI Jakarta dengan $53,67 \%$.

Menurut Seto (2004), salah satu factor yang sangat berpengaruh dalam persediaan obat di rumah sakit adalah pengontrolan jumlah stok obat untuk memenuhi kebutuhan. Jika stok obat terlalu kecil maka permintaan untuk penggunaan sering kali tidak terpenuhi sehingga pasien atau konsumen tidak puas, sehingga kesempatan untuk mendapatkan keuntungan dapat hilang dan diperlukan tambahan biaya untuk mendapatkan bahan obat dengan waktu cepat guna memuaskan pasien atau konsumen.
Jika stok terlalu besar maka menyebabkan biaya penyimpanan yang terlalu tinggi, kemungkinan obat akan menjadi rusak atau kadaluarsa dan ada resiko jika harga bahan atau obat turun.

Pada data sekunder yang diperolehdari RSUD Syekh Yusuf Gowa, pada tahun 2017 selama periode Januari-Juli 2017 terdapat 84 dari 205 jenis obat yang mengalami kekosongan. Informan menyebutkan bahwa pada gudang farmasi, kekosongan terjadi diakibatkan oleh peningkatan jumlah pasien yang secara otomatis mempengaruhi jumlah permintaan obat dari setiap bulannya. Jika pada bulan ini disediakan sekitar 500 stok obat dengan jenis tertentu, di bulan selanjutnya stok obat tersebut ditambahkan jika dirasa perlu. Namun belum tentu dapat memenuhi kebutuhan obat sebab peningkatan jumlah pasien sewaktu-waktu dapat berubah. Hal inilah yang membuat peneliti tertarik melakukan penelitian untuk melihat gambaran pengelolaan persediaan obat di Gudang Farmasi RSUD Syekh Yusuf Gowa Tahun 2017.

\section{METODE PENELITIAN}

Penelitian ini merupakan penelitian kualitatif dengan pendekatan studi kasus melalui wawancara mendalam dengan informan yang terdiri dari 1 orang informan kunci, 1 orang informan utama dan 2 orang informan biasa dengan teknik pengambilan 
sampel Teknik Non Random (Non Probability) Sampling dengan metode purposive sampling.

\section{HASIL PENELITIAN}

Input Pengelolaan Persediaan Obat

Pada penelitian yang dilakukan di Gudang Farmasi RSUD Syekh Yusuf Gowa diperoleh hasil bahwa sumber daya manusia yang terlibat dalam pengelolaan persediaan obat terdiri dari kepala instalasi farmasi, penanggung jawab pengelolaan farmasi, pengelola obat dan pengelola BMHP. Adapun informan lain menjelaskan bahwa bagian logistik dari masing-masing depo dan apotek juga terlibat dalam pengelolaan persediaan obat. Selanjutnya anggaran pengelolaan persediaan obat digunakan untuk pembelian sediaan farmasi yang mana seluruhnya itu telah tertuang dalam DPA.Terkait sarana dan prasarana dianggap sudah cukup memadai hanya saja beberapa informan menganggap perlunya penambahan komputer dan penambahan luas gudang penyimpanan sediaan farmasi. Selanjutnya terkait prosedur, seluruh kegiatan pengelolaan persediaan farmasi telah mengacu pada prosedur yang telah dibuat, berikut hasil wawancaranya.

"kalau di farmasi khususnya di BMHP itu kita ada staf, terus dengan masing-masing bagian logistic di ruangan. Klo untuk bagian obat yaa staf di sini ada 1 staf ada kepala penanggungjawab 1staf instalasi terus ada staf administrasi dan logistic. Terus kalo dibilang terlibat yaa semua juga bagian logistic dari masing-masing depo, apotik toh."

B, Laki-laki, 43 Tahun, 2017

"yaa di rumah sakit itukan sudah ada namanya DPA, di DPA itu sudah tertuang apa-apa yang mau dibelanja jadi kalo misalnya anggaran $A$ untuk belanja obat yaa kita harus belanja obat, B untuk belanja obat $B$, anggaran $C$ untuk pelatihan yaa harus digunakan untuk pelatihan. Itu kayak sudah dipaketpaketkan begitu"

TM, Perempuan, 46 Tahun, 2017

"kalau dianggap memadai yaa cukuplah tapi kalau kita mau yang ideal kan kita maunya kayak pake sistem yang komputerisasi, gudang yang memadai itu mungkin yang kurang tapi untuk melaksanakan pelayanan kefarmasian yaa lumayan mi itu"

TM, Perempuan, 46 Tahun, 2017

"Kalau untuk SOP yang sekarang iyaa sudah baik, ada sih satu-satu tapi kalo sifatnya cito kadangkadang dia langgar SOP nya gitu tpi itu tidak banyak sangat jarang jadi sudah lebih bagus"

B, Laki-laki, 43 Tahun, 2017

Proses Pengelolaan Persediaan Obat

Pada penelitian yang dilakukan di gudang farmasi RSUD Syekh Yusuf Gowa terkait proses pengelolaan persediaan obat yang mana terdiri dari pemilihan, perencanaan, pengadaan, penerimaan, 
penyimpanan,

pendistribusian,

penghapusan, pengendalian dan pencatatan.

Hasil penelitian menunjukkan bahwa proses pemilihan obat dilakukan dengan melihat kebutuhan user dan merujuk pada Formularium Nasional dan Formularium Rumah Sakit. Terkait perencanaan dilihat dari pemakaian obat pada bulan sebelumnya di masing-masing unit atau depo. Pengadaan obat di RSUD Syekh Yusuf Gowa sudah menggunakan sistem $e$ purchasing secara online melalui web LKPP (Lembaga Kebijakan Pengadaan barang/jasa Pemerintah). Berikut kutipan wawancaranya

"oiyaa di sini itu ada 2 dipake Formularium nasional dengan formularium rumah sakit"

R, Perempuan, 39 Tahun, 2017 "Tahapannya yaa dari masingmasing unit depo, apa yang dia butuhkan berapa jumlahnya nah kemudian di sini kita rangkum terus dilihat juga sebulannya pakai berapa gitu baru kita buat perencanaannya"

B, Laki-laki, 43 Tahun, 2017

"Pengadaan obatnya di sini itu pake itu hmm e-purchasing"

R, Perempuan, 39 Tahun, 2017

Pihak RSUD Syekh Yusuf membentuk panitia khusus untuk menerima sediaan barang yang datang, panitia tersebut disebut Panitia Penerima Barang.Proses penyimpanan obat di gudang farmasi RSUD
Syekh Yusuf Gowa dilakukan menurut abjad berdasarkan sediaan, stabilitas sediaan dan menggunakan metode FIFO dan FEFO. Distribusi obat yang dilakukan di RSUD Syekh Yusuf Gowa terbagi 2, pertama dengan cara resep dan kedua dengan cara mengampa. Tiap minggu petugas dari perawatan memiliki jadwal khusus untuk mengampra obat. Berikut kutipan wawancaranya

"oh begini misalnya itu obatnya sudah datang nanti diterima sama ada itu namanya Panitia Penerimaan Barang, terus nanti diteruskan ke penanggungjawab gudang. Nanti dicatatmi sama ibu Rifkah"

FA, Perempuan, 60 Tahun, 2017

"Sistem penyimpanan kalau obat kita atur abjad berdasarkan sediaan toh misalnya sediaan injeksi sama injeksi, yang kedua berdasarkan stabilitas yang stabilnya di ruangan dingin yaa di suhu dingin gitu”

B, Laki-laki, 43 Tahun, 2017

“...jadi distribusi obat itu ada 2 ada dengan cara per-resep ada dengan cara meng-ampra. Diperawatan itu mereka tiap minggu mengampra obat, ada permintaan khusus buatkan berita acara naah kalau dari pasien dia berdasarkan resep kan berapa dokter resepkan itu yang dikeluarkan"

TM, Perempuan, 46 Tahun, 2017

Proses penghapusan yang dilakukan di RSUD Syekh Yusuf Gowa sesuai dengan prosedur yang ada. Penghapusan yang dilakukan melibatkan pihak ketiga untuk membantu proses penghapusan perbekalan 
farmasi.Proses pengendalian persediaan yang dilakukan digudang farmasi adalah dengan cara memperhatikan stok obat yang kosong, dengan rutin membuat laporan pemakaian.Pencatatan yang dilakukan di gudang farmasi dilakukan secara rutin dan teratur.Sebab pencatatan bertujuan agar diperoleh laporan mengenai pemakaian sediaan dan bahan medis habis pakai di unit-unit pelayanan agar persediaan lebih terkontrol. Berikut hasil wawancaranya

"kita ajukan ke manajemen, manajemen nanti yang menyurat ke kantor daerah karna kita kan rumah sakit pemerintah toh baru bisa ini dilakukan pemusnahannya"

TM, Perempuan, 46 Tahun, 2017 "iyaaa. Pengendalian persediaan itu denganapa stok, stok barang. Barang yang keluar harus distok. Laporan tiap bulan, mereka harus buat laporan pemakaian, mutasi, berapa yang dipake berapa yang ini selain itu juga ada stock opnamenya toh"

TM, Perempuan, 46 Tahun, 2017

"Karena di sini kita buat laporan kan jadi pencatatan obat itu harus terus kita juga harus tertib gitu dalam pencatatannya"

B, Laki-laki, 43 Tahun, 2017

\section{Output Pengelolaan Persediaan Obat}

Hasil dari proses pengelolaan persediaan obat di gudang farmasi dianggap sudah cukup baik. Proses pengelolaan persediaan di gudang farmasi sudah mengi- kuti prosedur yang ada. Walaupun output yang dihasilkan belum sesuai dengan yang diharapkan.

"Pengelolaan sediaan yang dilakukan selama ini sudah cukup baik menurut saya yaa.Tapi terkadang masih ada sedikit-sedikit kendala tapi yaa cukup baikmi persediaannya"

B, Laki-laki, 43 Tahun, 2017

\section{PEMBAHASAN}

Input Pengelolaan Persediaan Obat

Sumber manusia merupakan salah satu faktor penting yang beberapa dalam pelaksanaan pengelolaan persediaan obat.berdasarkan hasil wawancara dan observasi bahwa jumlah sumber daya manusia yang ada di gudang farmasi berjumlah 5 orang. Satu orang sebagai penanggung jawab pengelola farmasi obat dan BMHP, satu orang bertugas sebagai pengelola obat dibantu dengan seorang staf administrasi, serta satu orang yang bertugas sebagai pengelola BMHP yang dibantu dengan seorang staf administrasi.

Berdasarkan Dirjen Bina Kefarmasian dan Alat Kesehatan tahun 2010, diketahui bahwa sumber daya manusia dalam pengelolaan persediaan obat di gudang farmasi terdiri dari satu orang atasan kepala gudang, satu orang kepala gudang, satu orang pengurus barang, dan satu orang pelaksana. 
Dalam pedoman pengelolaan obat yang dibuat oleh Dirjen Bina Farmasi dan Alat Kesehatan, 2010 menyebutkan bahwa salah satu input yang perlu disediakan dalam pengelolaan obat adalah anggaran. Sesuai dengan hasil wawancara peneliti yang menyebutkan bahwa anggaran yang ada di gunakan untuk pembeliaan sediaan farmasi serta untuk kegiatan pelatihan yang berkaitan dengan pengelolaan persediaan obat.hal tersebut telah tertuang dalam Dokumen Pelaksanaan Anggaran (DPA) yang telah dibuat oleh pihak rumah sakit.Begitu juga dengan fasilitas yang digunakan dalam pengelolaan persediaan obat di RSUD Syekh Yusuf Gowa.Berdasarkan hasil penelitian yang dilakukan di gudang farmasi RSUD Syekh Yusuf Gowa, diketahui bahwa fasilitas yang digunakan untuk pengelolaan persediaan obatsudah mencukupi.Fasilitas-fasilitas tersebut digunakan untuk mendorong terwujudnya pelayanan kefarmasian di gudang farmasi dengan baik. Menurut Ermiati dan Sembiring, 2012 dalam Badaruddin, 2015 mengatakan bahwa fasilitas adalah penyedia perlengkapan- perlengkapan fisik untuk memberikan kemudahan kepada penggunanya, sehingga kebutuhan-kebutuhan dari pengguna fasilitas tersebut dapatdipenuhi.

Prosedur yang berkaitan dengan pengelolaan persediaan obat sudah ada dan sudah digunakan sebagai acuan dalam pengelolaan obat di gudang farmasi RSUD Syekh Yusuf Gowa, meskipun petugas tidak mengingat seluruh prosedurnya secara mendetail.Selain itu, prosedur yang ada sudah dianggap efektif dalam menjalankan kegiatan pengelolaan persediaan di gudang farmasi RSUD Syekh Yusuf Gowa. Berbeda halnya dengan penelitian Mumek dkk, 2016 diketahui proses perencanaan dan pengadaan obat di instalasi farmasi RSUP Prof. Dr. R. D. Kandou Manado telah mengikuti prosedur sesuai dengan standar yang ada di rumah sakit akan tetapi belum efektif dalam penentuan beberapa jumlah atau volume yang direncanakan dan yang diadakan, sehingga menyebabkan kekurangan bahkan kelebihan obat.

\section{Proses Pengelolaan Persediaan Obat}

Berdasarkan hasil wawancara mendalam dapat diketahui bahwa proses pemilihan obat yang dilakukan oleh instalasi farmasi RSUD Syekh Yusuf Gowa berdasarkan pada pemakaian perbulan dari tiap user pada unit-unit pelayanan selanjutnya diteruskan kepada bagian gudang farmasi untuk dilakukan perencanaan sediaansediaan yang nantinya akan diadakan. Selain itu pemilihan sediaan farmasi dan $\mathrm{Ba}-$ han Medis Habis Pakai juga berlandaskan kepada Formularium Rumah Sakit yang disusun berdasarkan Formularium Nasional.Ini sejalan dengan hasil penelitian Nurlinda 
dkk, 2017 Pemilihan obat harus disesuaikan dengan formularium rumah sakit yang berdasarkan formularium nasional. Berdasarkan hasil wawancara dengan salah satu informan diketahui bahwa pemilihan obat yang akan diadakan disesuaikan dengan formularium RSUD Kabupaten Pangkep.

Menurut Seto, 2004 dalam Fadhila, 2013 perencanaan merupakan dasar tindakan manajer untuk dapat menyelesaikan tugas pekerjaannya. Penetuan kebutuhan merupakan perincian dari fungsi perencanaan menyangkut proses memilih jenis dan menetapkan dengan prediksi jumlah kebutuhan persediaan barang atau obat perjenis di apotek ataupun di rumah sakit. Penentuan kebutuhan obat di rumah sakit harus berpedoman kepada daftar obat essensial, formularium rumah sakit, standar terapi dan jenis penyakit di rumah sakit.

Hal ini sesuai dengan firman Allah swt. QS. al-Hasyr:18

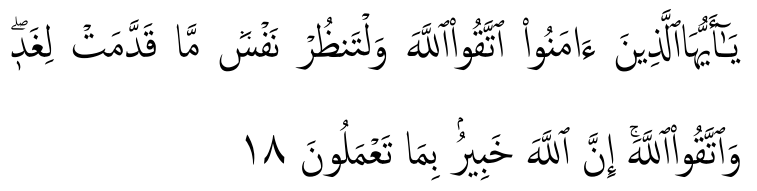

Terjemahnya:

"Hai orang-orang yang beriman, bertakwalah kepada Allah dan hendaklah Setiap diri memperhatikan apa yang telah diperbuatnya untuk hari esok (akhirat); dan bertakwalah kepada Allah, Sesungguhnya Allah Maha mengetahui apa yang kamu kerjakan" (Departemen
Agama RI, 2012).

Prof. Dr. Quraish Shihab dalamnya tafsir "al-Misbah" nya, menafsirkan bahwa ayat tersebut berbicara mengenai perencanaan. Beliau mengatakan bahwa kata 'waltandzur' nafsumma koddamat lighod", mempunyai arti bahwa manusia harus memikirkan terhadap dirinya dan merencanakan dari segala apa yang menyertai perbuatan selama hidupnya, sehingga ia akan memperoleh kenikmatan dalam kehidupan ini. Ayat ini berkaitan dengan proses perencanaan kebutuhan di gudang farmasi RSUD Syekh Yusuf Gowa yang dilaksanakan oleh petugas gudang bahwa perencanaan yang dilakukan harus berdasarkan kepada kebutuhan user serta prosedur yang telah ditetapkan agar proses perencanaan dapat berlangsung dengan baik.

Menurut Permenkes No. 72 Tahun 2016 pengadaan merupakan kegiatan yang dimaksudkan untuk merealisasikan perencanaan kebutuhan. Pengadaan merupakan kegiatan yang berkesinambungan dimulai dari pemilihan, penentuan jumlah yang dibutuhkan, penyesuaian antara kebutuhan dan dana, pemilihan metode pengadaan, pemilihan pemasok, penentuan spesifikasi kontrak, pemantauan proses pengadaan, dan pembayaran.

Dari hasil wawancara dengan be- 
berapa informan, pengadaan dilakukan dengan sistem e-purchasing dan sistem tender. Sistem e-purchasing dilakukan agar mempermudah petugas dalam melakukan pembelian, karena barang atau obat yang akan dibeli dalam e-catalog sudah memuat daftar, jenis, dan spesifikasi termasukhargaobattersebut. Dalam penelitian Sumangkut dan Jansen (2014) menyebutkan hal yang sama yaitu pengadaan secara e- purchasing dilakukan secara langsung kepada penyedia barang, pengadaan seperti ini untuk mempermudah petugas dalam melakukan pemesanan barang kepada penyedia barang.

Berdasarkan hasil wawancara mendalam, informan mengungkapkan bahwa penerimaan sediaan yang datang dari distributor diterima oleh Panitia Penerimaan Barang yang dibentuk khusus untuk menerima dan mengecek sediaan farmasi dan $\mathrm{Ba}-$ han Medis Habis Pakai yang datang.Tujuan dari dilakukannya penerimaan barang ini adalah menjamin sediaan farmasi dan Bahan Medis Habis Pakai yang diterima dari distributor dengan mengecek jumlah barang, jenis barang serta mutu dari sediaan yang datang.Selain itu informan juga mengatakan bahwa Panitia Khusus rutin melakukan pengecekan tanggal kadalaursa dari sediaan yang diterima. Ini sejalan dengan hasil penelitian Malinggas dkk, 2015 hasil wawancara dari semua informan menunjukkan bahwa obat-obat yang dipesan sebelum dimasukkan di gudang farmasi, diterima oleh panitia penerimaan barang kesesuaian akan jenis, jumlah, expired date, serta faktur yang ada untuk menjadi dokumen pegangan oleh instalasifarmasi dan panitia penerimaan barang. Berbeda halnya dengan penelitian Mawaddah dkk, 2016 Penerimaan obat di Instalasi Farmasi RS Islam Fasial dilakukan dengan cara pengecekan status pemesanan di komputer. Untuk bagian penerimaan di Instalasi Farmasi RS Islam Faisal tidak ada panitia khusus.

Berdasarkan hasil penelitian yang dilakukan bahwa pelaksanaan kegiatan penyimpanan obat di gudang farmasi RSUD Syekh Yusuf Gowa menggunakan sistem FIFO dan FEFO. Artinya dalam penyusunan, obat-obatan yang baru datang diletakkan di belakang dan obat-obatan yang lama diletakkan di bagian depan. Selain menggunakan sistem FIFO dan FEFO, proses penyimpanan obat di gudang farmasi RSUD Syekh Yusuf Gowa berdasarkan pada abjad dan kestabilan sediaan.Artinya sediaan farmasi diatur berdasarkan abjad agar lebih memudahkan pada saat pencarian sediaan, sedangkan penyimpanan berdasarkan kestabilan sediaan, artinya sediaan yang seharusnya diletakkan di suhu ruangan yang dingin harus diletakkan sebagaimana mestinya agar menghindari kerusakan obat. Ini sejalan dengan penelitian Mongi dan Grace, 2015 diketahui Penyimpanan obat di IFR- 
SAD R.W. Mongisidi Manado menggunakan metode First In First Out (FIFO) dan First Expired First Out (FEFO). Penyimpanan disusun di rak lemari berdasarkan alfabet.

Proses pendistribusian obat yang dilakukan di gudang farmasi RSUD Syekh Yusuf Gowa melalui dua proses yaitu melalui peresepan dan pengampraan. Pendistribusian obat dimulai dari gudang farmasi dengan menerima lembar permintaan obat dari unit pelayanan, kemudian distribusi obat menyesuaikan dengan persediaan yang ada di gudang farmasi.Pihak gudang farmasi memberi jadwal pengampraan kepada penanggung jawab di unit pelayanan agar pengampraan lebih teratur.Ini sejalan dengan penelitian Hiborang, 2016 pendistribusian obat dimulai dari Gudang Farmasi di Dinas Kesehatan Kota Manado dengan menerima lembar permintaan obat dari Puskesmas, kemudian didistribusi obat menyesuaikan dengan persediaan atau buffer stok, yang ada digudang.

Penghapusan dan pemusnahan merupakan suatu kegiatan untuk menghapus atau memusnahkan sediaan farmasi yang sudah tidak terpakai karena kadaluarsa atau rusak, mutu tidak memenuhi standar dengan cara membuat usulan penghapusan perbekalan farmasi kepada piha terkait sesuai dengan prosedur yang berlaku. Pelaksanaan kegiatan penghapusan dan pemusnahan sediaan dan BMHP di RSUD Syekh Yusuf Gowa dilakukan dengan cara seluruh sediaan yang telah kadaluarsa ataupun rusak dikumpulkan pada gudang farmasi RSUD Syekh Yusuf Gowa, setelah itu pihak gudang farmasi membuat usulan berupa berita acara penghapusan yang sebelumnya telah disetujui oleh kepala instalasi farmasi. Lain halnya dengan penelitian Hasratna, 2016 diketahui di Rumah Sakit Umum Daerah Kabupaten Muna belum pernah diadakan pemusnahan obat dikarenakan laporan untuk pelaksanaan pemusnahan obat belum di ACC oleh direktur Rumah Sakit Umum Daerah Kabupaten Muna sehingga penyimpanan sementara untuk obat yang sudah kadaluwarsa atau rusak ditempatkan tersendiri agar tidak teracampur dengan obat yang tidak rusak.Selanjutnya, berita acara penghapusan dan pemusnahan tersebut diajukan kepada pihak manajemen untuk dilanjutkan kepada pihak terkait. Proses penghapusan dan pemusnahan sediaan farmasi dan BMHP RSUD Syekh Yusuf Gowa tidak dilakukan di dalam ruang lingkup rumah sakit, tetapi pihak rumah sakit bekerjasama dengan pihak luar.

Untuk mengendalikan ketersediaan obat tersebut agar selalu dapat memenuhi kebutuhan untuk setiap pasien merupakan 
suatu hal yang tidak mudah. Dari hasil penelitian melalui wawancara dengan keempat informan dan observasi di gudang farmasi RSUD Syekh Yusuf Gowa diketahui bahwa kegiatan pengendalian yang dilakukan dengan melihat stock opname dan rutin melakukan pencatatan. Menurut Dirjend Kefarmasian dan Alat Kesehatan RI, 2010 dalam Febriawati, 2013stock opname diperlukan untuk kebutuhan audit dan perencanaan yang wajib dilaksanakan. Stock opname merupakan salah satu cara menilai kelancaran kegiatan penyimpanan dan pencatatanya. Oleh karena itu hasil stock opname harus sesuai antara data pencatatan dengan jumlah stok fisik di gudang farmasi. Jika terdapat ketidaksesuaian harus segera dilakukan analisis untuk mengetahui kerugiannya.

Berdasarkan hasil wawancara mendalam diketahui bahwa pencatatan obat masuk dan obat keluar rutin dilakukan sebab melalui pencatatan yang dilakukan tersebut pemasukan dan pengeluaran obat dapat terkontrol. Pencatatan yang dilakukan juga harus sesuai dengan pelayanan kebutuhan di RSUD Syekh Yusuf Gowa. Selain pencatatan stok obat yang masuk dan keluar, pihak gudang farmasi juga melakukan pencatatan terhadap sediaan yang kadaluarsa ataupun rusak hal ini bertujuan untuk mengendalikan sediaan yang ada.Menurut Permenkes No. 72 Tahun Pencatatan dan pela- poran terhadap kegiatan pengelolaan Sediaan Farmasi, Alat Kesehatan, dan Bahan Medis Habis Pakai yang meliputi perencanaan kebutuhan, pengadaan, penerimaan, pendistribusian, pengendalian persediaan, pengembalian, pemusnahan dan penarikan Sediaan Farmasi, Alat Kesehatan, dan Bahan Medis Habis Pakai. Pelaporan dibuat secara periodik yang dilakukan Instalasi Farmasi dalam periode waktu tertentu (bulanan, triwulanan, semester atau pertahun).

Output Pengelolaan Persediaan Obat

Berdasarkan hasil penelitian diketahui bahwa ketersediaan obat di gudang farmasi telah sesuai dengan kebutuhan, akan tetapi ada beberapa obat terkadang masih terjadi terjadi kekosongan obat di gudang farmasi, hal ini disebabkan salah satunya oleh peningkatan jumlah pasien. Berdasarkan data sekunder yang diperoleh, pada tahun 2017 selama periode Januari-Juli 2017 terdapat 84 dari 205 jenis obat yang mengalami kekosongan. Informan menyebutkan bahwa pada gudang farmasi, kekosongan terjadi diakibatkan oleh peningkatan jumlah pasien yang secara otomatis mempengaruhi jumlah permintaan obat dari setiap bulannya. Jika pada bulan ini disediakan sekitar 500 stok obat dengan jenis tertentu, di bulan selanjutnya stok obat tersebut ditambahkan jika dirasa perlu. $\mathrm{Na}$ mun belum tentu dapat memenuhi kebutu- 
han obat sebab peningkatan jumlah pasien sewaktu-waktu dapat berubah.

\section{KESIMPULAN}

Berdasarkan hasil penelitian mengenai gambaran pengelolaan persediaan obat di instalasi farmasi RSUD Syekh Yusuf Gowa Tahun 2017 dapat disimpulkan bahwa sebagai berikut: (1) Input Pengelolaan Persediaan Obat (sarana dan prasarana terutama gudang penyimpanan masih kurang representatif). (2) Proses Pengelolaan Persediaan Obat (Ketidakkonsistenan terhadap penggunaan sediaan, perencanaan kurang teliti sehingga mengakibatkan ada item obat yang terlupa untuk direncanakan, suhu gudang yang berubah-ubah dapat mempengaruhi sediaan yang ada, keterlambatan pelaporan sediaan yang kosong dan kelalaian petugas yang mengakibatkan sediaan menjadi rusak dan expired). (3) Output Pengelolaan Persediaan Obat (Sudah sesuai kebutuhan, tetapi seringkali juga terjadi kekosongan obat yang disebabkan salah satunya oleh peningkatan jumlah pasien. Harapan dari para informan adalah sediaan yang ada stabil dan dapat memenuhi kebutuhan di RSUD Syekh Yusuf Gowa selain itu mereka mengharapkan angka kekosongan obat dan kelebihan obat diminimalisir sekecil mungkin).
Adapun saran dari penelitian ini antara lain sebagai berikut: (1) Diharapkan kepada Kepala Instalasi Farmasi RSUD Syekh Yusuf Gowa untuk mempertimbangkan penambahan luas gudang farmasi yang dianggap belum cukup memadai. (2) Diharapkan kepada Kepala Instalasi Farmasi RSUD Syekh Yusuf Gowa untuk pengadaan pendingin ruangan yang sesuai dengan standar. (3) Diharapkan kepada petugas gudang untuk lebih teliti dalam proses perencanaan sediaan untuk meminimalisir sediaan yang terlupa. (4) Bagi peneliti selanjutnya agar dapat mengkaji lebih dalam dan melihat faktor-faktor yang lain sehingga dapat dibandingkan dengan penelitian ini dan diperoleh hasil yang lebih variatif.

\section{DAFTAR PSUTAKA}

Badaruddin, M. (2015). Gambaran Pengelolaan Persediaan Obat di Gudang farmasi Rumah Sakit Umum Daerah Kota Sekayu kabupaten Musi Bayuasin Palembang Tahun 2015. Jakarta: Universitas Islam Negeri SyarifHidayatullah

Departemen Agama RI. (2010). AlQur'an dan Terjemahnya.Semarang:CV. Toha Putra.

Ditjen Bina Kefarmasian dan Alat Kefarmasian. (2010). Rencana Strategi Kementrian Kesehatan 20102014

Ditjen Kefarmasian dan Alat Kesehatan. (2017). Menjamin Aksebilitas Obat dan Alat Kesehatan di Daerah 
Fadhila, R.(2013). Studi Pengendalian Persediaan Obat Generik Melalui Metode Analisis ABC, Economic Order Quantity (EOQ) dan Reorder Point (ROP) di Gudang Farmasi Rumah Sakit Islam Asshobirin. Jakarta: Universitas Islam Syarif Hidayatullah

Febriawati, H. (2013). Manajemen Logistik Farmasi Rumah Sakit. Yogyakarta: Gosyen Publishing

Hasratna, dkk. (2016). Gambaran Pengelolaan Persediaan Obat di Instalasi farmasi Rumah Sakit Umum daerah kabupaten Muna Tahun 2016. Jurnal Universitas Halu Oleo, 1-7.

Hariyanti, D.dkk. (2015). Perencanaan Obat Berdasarkan Analisis Always Better Control (ABC) dan Economic Order Quantity (EOQ) di Instalasi Farmasi RSUD Melawi Kabupaten Melawi Kalimantan Barat Pontianak: Universitas Tanjungpura.

Hiborang, S. dkk. (2016). Gambaran Pelaksanaan Pengelolaan Obat di Puskesmas Paniki Bawah Kota Manado Tahun 2016. Jurnal Universitas Sam Ratulangi, 1-8.

Malinggas, N. E.R. dkk. (2015). Analisis Manajemen Logistik Obat diInstalasi Farmasi Rumah Sakit Umum Daerah DR Sam Ratulangi Tondano. Jurnal Universitas Sam Ratulangi, 5: 1-13
Mawaddah, S. dkk.(2016). Gambaran Manajemen Logistik Obat-obatan di Instalasi Farmasi Rumah Sakit Islam Faisal Makassar Tahun 2016. Makassar:Universitas Islam Negeri Alauddin Makassar

Mongi. J dan Grace D. K. (2015). Implementasi Pelayanan Kefarmasian di Instalasi Farmasi Rumah Sakit Angkatan Darat Robert Wolter Monginsidi Manado. Jurnal Universitas Sam Ratulangi Manado, 1: 1-23.

Mumek, V M. Dkk. (2016). Evaluasi Perencanaan danPengadaan Obat di Instalasi Farmasi RSUP Prof. DR. R.D Kandau Manado Berdasarkan Analisis ABC-VEN. Jurnal Ilmiah FarmasiUNSRAT, 5: 1-5.

Nurlinda. dkk. (2016). Studi Tentang Manajemen Pengelolaan Obat Di Instalasi Farmasi Rumah Sakit Umum Daerah Kabupaten Pangkep. Jurnal Universitas Hasanuddin, 1-15.

Permenkes No. 72 tahun 2016. Standar Pelayanan Kefarmasian di Rumah Sakit.

Seto, S. dkk. (2004).Manajemen Farmasi:Apotek, Farmasi RumahSakit, Pedagang Besar Farmasi,dan Industri Farmasi. Airlangga University Press. 